Imágenes en Urología

\title{
Calcificación bilateral de vesículas seminales y conductos deferentes
}

\author{
Francisco J. González Ortega, S. Duque Fernández de Vega, F. Garrido Pareja
}

Servicio de Radiodiagnóstico. Hospital Clínico San Cecilio. Granada, España

$\mathrm{V}$

arón de 67 años que acude al nuestro servicio para la realización de una TC basal abdominopélvica por presentar elevación mantenida del marcador tumoral CA-19.9 con ecografia previa negativa.

La tomografía no evidencia lesiones orgánicas sospechosas. En cambio se observa como hallazgo incidental la calcificación bilateral y simétrica de las vesículas seminales (Fig. 1, flechas cortas), y de los conductos deferentes en su trayecto intrapélvico (Fig. 1, flechas largas) y en la porción visualizada de los conductos inguinales (Fig.1, flechas curvas). En

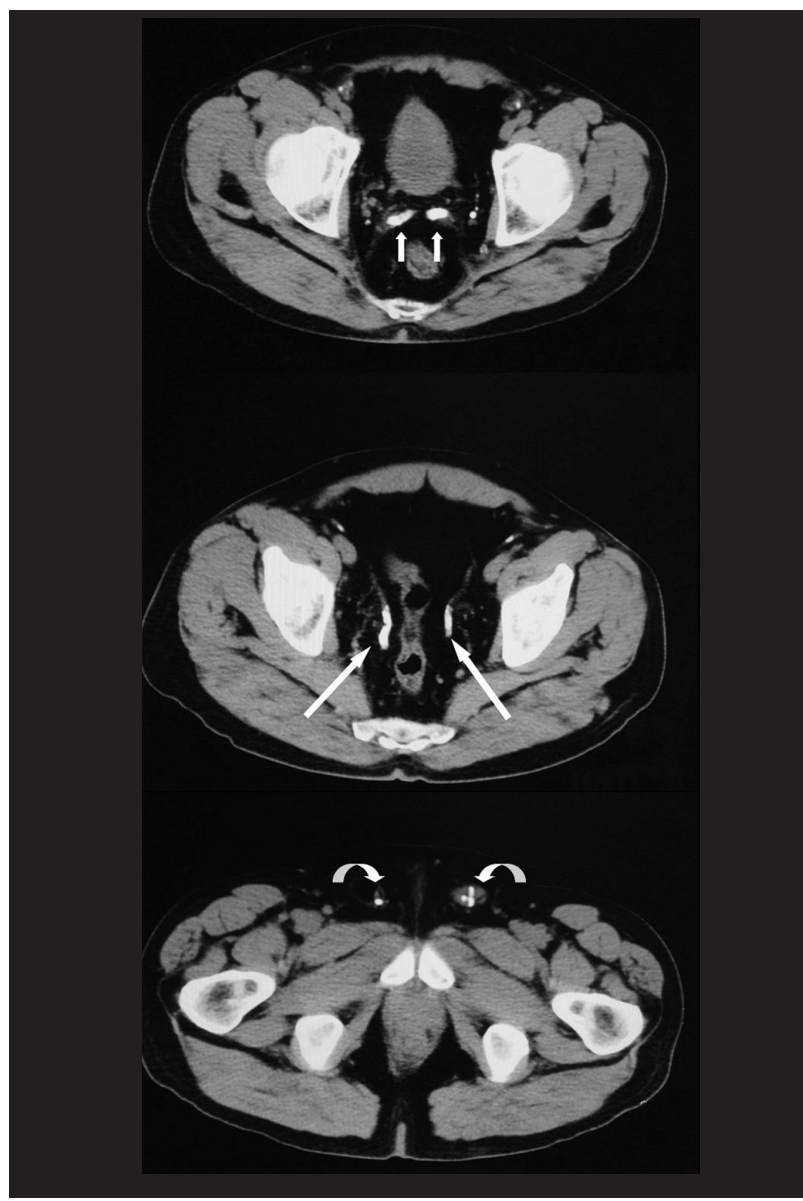

FIGURA 1

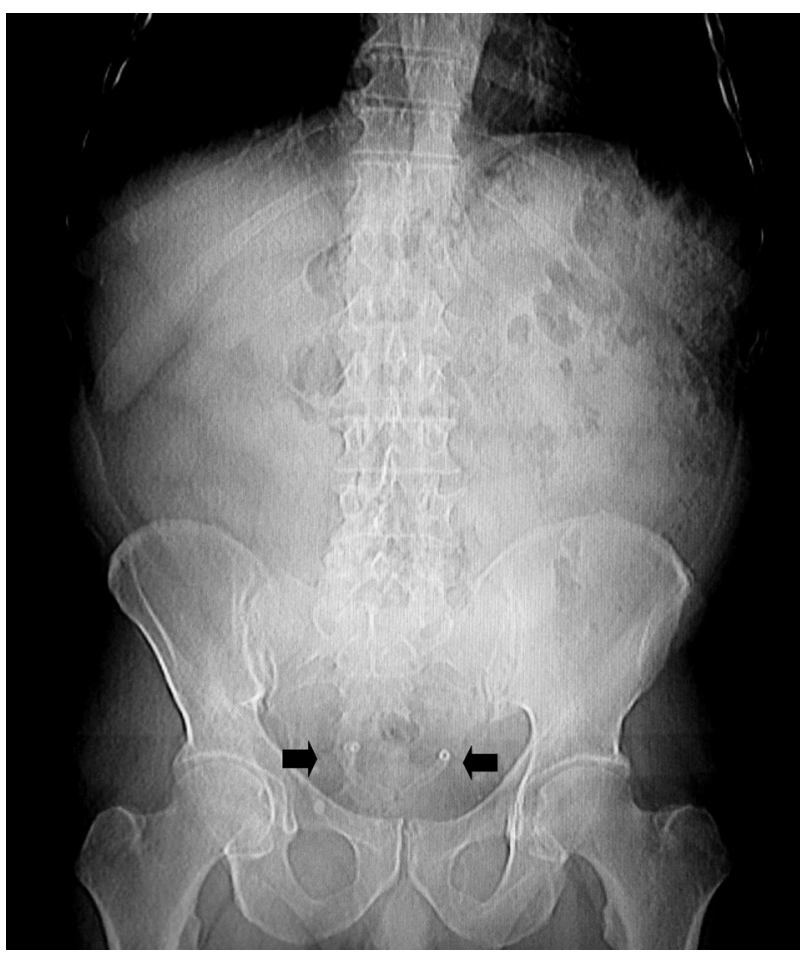

FIGURA 2

una radiografía simple de abdomen previa se observan dos imágenes tubulares de alta densidad en pelvis que se corresponden con los conductos deferentes calcificados (Fig. 2, flechas negras).

A posteriori se supo que el paciente padecía diabetes mellitus tipo I, una de las causas que explicarían nuestros hallazgos según la literatura. Otras alteraciones que también pueden provocar calcificaciones similares son la prostatitis, la tuberculosis genitourinaria y algunas disgenesias gonadales.

Correspondencia autor: Dr. Francisco J. González Ortega Servicio de Radiodiagnóstico. Hospital Clínico San Cecilio Avda. del Doctor Olóriz, 16 - 18012 Granada Tel.: 958023308

E-mail autor: colodrillo@gmail.com

Información artículo: Imágenes en Urología

Trabajo recibido: septiembre 2007

Trabajo aceptado: octubre 2007 